\title{
HUBUNGAN ANTARA KEBIASAAN SARAPAN DAN KEBIASAAN JAJAN DENGAN STATUS GIZI ANAK SEKOLAH DASAR DI KECAMATAN PEDURUNGAN KOTA SEMARANG
}

\author{
Yuni Yanti Mariza, Aryu Candra Kusumastuti ${ }^{*}$ \\ Program Studi Ilmu Gizi Fakultas Kedokteran Universitas Diponegoro \\ Jl.Dr.Sutomo No.14, Semarang, Telp (024) 8453708, Email : gizifk@undip.ac.id
}

\begin{abstract}
Background : The increasing prevalence of obesity in children need to become a public concern. Obesity in children and adolescents can ongoing process to adulthood and can be risk factor of degenerative diseases. Breakfast skipping habit and consuming more energy dense snack might be associated with obesity. This study aims to determine the relationship of breakfast consumption habit and snacking habit with nutritional status and the incidence of obesity and overweight among elementary school students.

Methods: The study was conducted in 2 elementary schools in Pedurungan sub-district. This is Case-control study with 64 subjects consisting 32 cases and 32 controls. Selection of sample by simple random sampling of classes 3 until 6. Data breakfast consumption habit and snacking habit obtained from a food recall for a week.

Results: The prevalence of overweight and obesity are $11.7 \%$ and $8 \%$ respectively. This study found 13 subject ( $40,62 \%)$ in cases and 15 subject (46,87\%) in control group which is not habitually breakfast and breakfast habit has not effect with nutritional status ( $p=0.614 ; O R=0,636 ; C I=0.479-3.470)$. The result also shows 29 subject cases group $(90,65 \%)$ and 5 subjects $(53,15 \%)$ control group habitually snacking and snacking has relationship with obesity and overweight ( $p=0.001 ; O R=7.012 ; C I=2.153-33.788)$. There were 28 subjects $(43,76)$ which is not habitually breakfast but snacking, and there is no subject which is not habitually breakfast but not snacking (0\%) and there is a significant relationship between the snacking habbit with breakfast ( $p=0,000 ; O R=1.500 ; C I=0.361$ 0.693).
\end{abstract}

Conclusion: There is a relationship between the breakfast habbit with snacking habbit. Skipping breakfast can increase the risk of snacking 1,5 times. There is a relationship between the snacking habbit with overnutrition. Snacking habbit also can increase the risk of overnutrition 7 times.

Key words: breakfast; snacking habbit; nutritional status

\begin{abstract}
ABSTRAK
Latar Belakang: Meningkatnya prevalensi obesitas pada anak perlu menjadi perhatian publik. Obesitas pada anakanak dan remaja dapat berlangsung hingga dewasa dan dapat menjadi faktor risiko dari berbagai penyakit degeneratif. Meninggalkan sarapan dan mengkonsumsi makanan jajanan tinggi kalori dapat menyebabkan obesitas. Penelitian ini bertujuan untuk mengetahui hubungan kebiasaan sarapan dan kebiasaan jajan dengan status gizi dan besar risiko terhadap kejadian obesitas dan kegemukan pada anak sekolah dasar.

Metode : Penelitian dilakukan di 2 SD di kecamatan Pedurungan kota Semarang. Desain penelitian kasus kontrol dengan jumlah subyek sebesar 64 yang terdiri dari 32 kasus dan 32 kontrol. Pemilihan sampel penelitian menggunakan simple random sampling pada anak kelas 3 sampai dengan kelas 6. Data kebiasaan sarapan dan kebiasaan jajan diperoleh dari wawancara secara langsung menggunakan metode Food Recall selama seminggu.

Hasil : Prevalensi overweight dan obesitas sebesar 11,7\% dan 8\%. Pada penelitian ini ditemukan 13 subjek (40,62\%) pada kelompok kasus dan 15 subjek (46,87\%) pada kelompok kontrol yang tidak biasa sarapan dan tidak terdapat hubungan antara kebiasaan sarapan dengan status gizi $(p=0.614 ; O R=0,636 ; C I=0.479-3.470)$. Hasil penelitian juga menunjukkan 29 subjek (90,65\%) kelompok kasus dan 17 subjek $(53,15 \%)$ kelompok kontrol biasa jajan dan terdapat hubungan antara kebiasaan jajan terhadap kejadian obesitas dan kegemukan ( $p=0.001 ; 0 R=$ 7.012; $C I=2.153-33.788)$. Terdapat 28 subjek (43,76\%) yang tidak biasa sarapan tetapi biasa jajan, dan tidak terdapat subjek yang tidak biasa sarapan tetapi tidak biasa jajan. Terdapat hubungan yang bermakna antara kebiasaan sarapan dengan kebiasaan jajan ( $p=0,000 ; O R=1.500 ; C I=0.361-0.693$ )

Simpulan : Kebiasaan sarapan berhubungan dengan kebiasaan jajan. Tidak biasa sarapan dapat meningkatkan risiko biasa jajan sebesar 1,5 kali. Kebiasaan jajan berhubungan dengan status gizi. Biasa jajan meningkatkan risiko terjadinya status gizi lebih sebesar 7 kali.
\end{abstract}

Kata kunci : Kebiasaan sarapan; kebiasaan jajan; status gizi

\footnotetext{
${ }^{*}$ Penulis Penanggungjawab
} 


\section{PENDAHULUAN}

Visi Indonesia Sehat 2015 bertujuan untuk mensejahterakan rakyat dalam peningkatan kesehatan termasuk gizi. Undang-undang nomor 36 Tahun 2009 tentang Kesehatan pasal 141 ayat 1 menyatakan bahwa upaya perbaikan gizi masyarakat ditujukan untuk peningkatan mutu gizi perseorangan dan masyarakat. ${ }^{1}$

Salah satu upaya peningkatan kesehatan adalah perbaikan gizi terutama pada usia sekolah khususnya 6-12 tahun. Makan pagi atau sarapan adalah kegiatan mengkonsumsi makanan yang mengandung gizi seimbang dan memenuhi $20 \%$ $25 \%$ dari kebutuhan energi total dalam sehari yang dilakukan pada pagi hari sebelum kegiatan belajar di sekolah. ${ }^{2}$ Sarapan pagi pada anak sekolah bertujuan untuk mencukupi kebutuhan energi selama beraktivitas di sekolah serta dapat meningkatkan konsentrasi dan daya ingat anak. Kebiasaan sarapan juga termasuk dalam salah satu 13 pesan dasar gizi seimbang. ${ }^{3}$

Sarapan sebaiknya mengandung makanan sumber karbohidrat, protein, tinggi serat, dan rendah lemak. ${ }^{4}$ Melewatkan sarapan dapat berisiko untuk menjadi obesitas dan memiliki gangguan kesehatan. $^{5}$ Obesitas dapat terjadi karena ketika anak tersebut melewatkan sarapan dan merasa lapar maka mereka akan mengkonsumsi makanan berkalori lebih tinggi yang didapatkan dari makanan jajanan. ${ }^{5,6}$ Penelitian di Amerika Serikat menunjukkan bahwa anak-anak dan remaja yang terbiasa melewatkan sarapan akan memiliki risiko 3 kali lebih tinggi untuk ngemil dan sulit mengontrol nafsu makan mereka sehingga dapat menyebabkan obesitas. ${ }^{7}$

Penelitian yang dilakukan Triyanti di SD Citarum 01,02,03, dan 04 Semarang menunjukkan masih terdapat $34,83 \%$ anak SD jarang sarapan dan terdapat hubungan antara kebiasaan makan pagi dengan prestasi belajar. ${ }^{8}$ Survey yang dilakukan Pergizi Pangan Indonesia tahun 2010 pada 35 ribu anak usia sekolah dasar menunjukkan $44,6 \%$ anak yang sarapan memperoleh asupan energi kurang dari $15 \%$ kebutuhannya.

Kelaparan saat di sekolah akan menyebabkan anak jajan di sekolah, apalagi hanya sekitar 5\% dari anak-anak tersebut membawa bekal dari rumah, sehingga kemungkinan untuk membeli makanan jajanan lebih tinggi. ${ }^{9}$ BPOM RI tahun 2009 dalam Pangan Jajanan Anak Sekolah menunjukkan bahwa makanan jajanan memberikan kontribusi masing-masing sebesar $31,1 \%$, dan $27,4 \%$ terhadap keseluruhan asupan energi dan protein anak sekolah dasar. ${ }^{10}$ Sebuah studi di
Amerika Serikat menunjukkan bahwa anak mengkonsumsi lebih dari sepertiga kebutuhan kalori sehari yang berasal dari makanan jajanan jenis fast food dan soft drink dapat menyebabkan obesitas. $^{11}$

Hasil RISKESDAS tahun 2010 menunjukkan prevalensi overweight dan obesitas pada anak sekolah (6-12 tahun) sebesar 9,2\%. Sejak tahun 1970 hingga 2010, kejadian obesitas meningkat dua kali lipat pada anak usia 2-5 tahun dan usia 12-19 tahun, bahkan meningkat tiga kali lipat pada anak usia 6-11 tahun. Di Indonesia, penelitian pada anak sekolah dasar di beberapa kota besar menunjukkan kisaran jumlah 2,1-25\%. ${ }^{12}$

Prevalensi obesitas pada anak sekolah usia 6-12 tahun di propinsi Jawa Tengah pada tahun 2010 lebih tinggi dari prevalensi nasional yaitu 10,9\%. Prevalensi obesitas dan overweight di Semarang tahun 2004 pada murid sekolah dasar usia 6-7 tahun adalah sebesar $10,6 \%$ dan $9,1 \% .{ }^{13}$ Obesitas pada dewasa dapat bermula semenjak anak-anak, dan obesitas dapat menjadi faktor risiko dari berbagai penyakit degeneratif seperti hipertensi, diabetes mellitus, dan jantung. ${ }^{14}$

Pedurungan merupakan salah satu kecamatan di kota Semarang bawah yang sebagian besar daerahnya dimanfaatkan untuk pusat industri, perdagangan,dan pendidikan. Sebaran sosial ekonomi keluarga yang bervariasi di kecamatan Pedurungan juga dapat menggambarkan prevalensi obesitas untuk populasi secara umum di kota Semarang. Kepadatan penduduk tergolong tinggi yaitu $7.453 / \mathrm{km}^{2}$ dan pertumbuhan penduduk anak usia sekolah 5-14 tahun 1,87\% . Survey langsung yang dilakukan di beberapa sekolah dasar negeri di Pedurungan, terdapat banyak penjual makanan maupun minuman jajanan di sekitar sekolah.

Pada screening awal di kecamatan Pedurungan ditemukan prevalensi status gizi lebih yang tergolong tinggi yaitu $19,7 \%$. Belum terdapat data dan penelitian mengenai kebiasaan sarapan dan kebiasaan jajan kaitannya dengan status gizi di kecamatan Pedurungan. Penelitian ini bertujuan untuk mengetahui hubungan kebiasaan sarapan dan kebiasaan jajan dengan status gizi pada anak sekolah dasar di kecamatan Pedurungan kota Semarang.

\section{METODE PENELITIAN}

Penelitian ini merupakan penelitian observasional dalam bidang gizi masyarakat dengan rancangan case control study yang dilakukan pada bulan Oktober 2012. Populasi target dalam penelitian ini adalah anak-anak yang 
mengikuti pendidikan formal Sekolah Dasar di Kecamatan Pedurungan, dan populasi terjangkaunya adalah semua siswa dan siswi sekolah dasar di SDN Pedurungan Kidul 01 dan SDN Palebon 03. Besar sampel minimal masingmasing kelompok kasus status gizi lebih dan kontrol status gizi normal berjumlah 32 sampel dihitung dengan menggunakan rumus case control berpasangan.

Penelitian diawali dengan melakukan screening terhadap siswa kelas 3-6 yang meliputi berat badan dan tinggi badan untuk mendapatkan prevalensi status gizi lebih. Pengukuran berat badan menggunakan timbangan digital dengan ketelitian $0,1 \mathrm{~kg}$ dan pengukuran tinggi badan menggunakan microtoise dengan ketelitian $0,1 \mathrm{~cm}$ dimana saat pengukuran subjek tidak memakai sepatu dan ikat pinggang. Setelah itu dilakukan teknik simple random sampling untuk mengambil sampel dari kelompok kasus dan kelompok kontrol. Data yang dikumpulkan meliputi data kebiasaan sarapan dan kebiasaan jajan dengan menggunakan formulir recall. Kebiasaan sarapan dan jajan diperoleh melalui wawancara dan dihitung berdasarkan banyaknya responden melakukan sarapan dan jajan dalam seminggu serta jumlah kalori yang diperoleh dari kebiasaan tersebut selama seminggu. Kebiasaan sarapan dikategorikan biasa jika dalam seminggu melakukan sarapan $\geq 4$ kali dan mengandung energi $20-25 \%$ dari kebutuhan total sehari, dikategorikan tidak biasa jika dalam seminggu melakukan sarapan $<4$ kali dan mengandung energi $<20-25 \%$ dari kebutuhan total sehari. Kebiasaan jajan dikategorikan biasa jika $\geq 5$ kali seminggu dan $\geq 10 \%$ kebutuhan energi total, dikategorikan tidak biasa jika $<5$ kali seminggu dan $<10 \%$ kebutuhan energi total.

Analisis data menggunakan univariat dan bivariat. Status gizi dinyatakan berdasarkan nilai zscore menurut WHO 2007 yang dihitung menggunakan software WHO Anthroplus. Data yang berskala kategorik seperti jenis kelamin, usia, kategori kebiasaan sarapan dan kategori kebiasaan jajan dideskripsikan sebagai distribusi frekuensi dan persen. Analisis bivariat menggunakan uji $M c$ Nemar dengan tingkat kemaknaan 5\%.

\section{HASIL PENELITIAN \\ Karakteristik Subjek}

Hasil penelitian pendahuluan dari 426 subjek ditemukan 84 subjek termasuk status gizi lebih yaitu overweight 50 subjek $(11,7 \%)$ dan obesitas 34 subjek (8\%), 320 subjek adalah status gizi normal $(75,1 \%)$, dan 22 anak termasuk dalam status gizi kurang $(5,2 \%)$. Distribusi status gizi pada subjek dapat dilihat pada tabel 1 dan karakteristik subjek penelitian pada tabel 2 .

\section{A. Analisis Deskriptif}

Penentuan status gizi lebih berdasarkan nilai z-score menurut WHO 2007 dikategorikan menjadi 2 kategori, yaitu overweight dan obesitas. Overweight yaitu nilai z-score $+1 \mathrm{SD} \mathrm{s} / \mathrm{d} \leq+2 \mathrm{SD}$ dan obesitas yaitu nilai $z$-score $>+2$ SD. Status gizi subjek di kecamatan Pedurungan dapat dilihat pada tabel 1 .

Tabel 1. Distribusi Status Gizi Pada Anak Sekolah Dasar di SDN Pedurungan Kidul 01 dan SDN Palebon 03

\begin{tabular}{ccccccc}
\hline $\begin{array}{c}\text { Karakteristi } \\
\mathbf{k}\end{array}$ & \multicolumn{2}{c}{ Lebih } & & & & \\
\cline { 2 - 4 } & Overweight & $\begin{array}{c}\text { Obesita } \\
\mathbf{s}\end{array}$ & Total & Normal & Kurang & Total \\
\hline Usia & & & & & & \\
8 tahun & 14 & 9 & $23(5,4 \%)$ & $63(14,8 \%)$ & $7(1,6 \%)$ & $93(21,8 \%)$ \\
9 tahun & 9 & 5 & $14(3,3 \%)$ & $74(17,4 \%)$ & $6(1,4 \%)$ & $94(22,1 \%)$ \\
10 tahun & 7 & 6 & $13(3,05 \%)$ & $79(18,5 \%)$ & $3(0,7 \%)$ & $95(22,3 \%)$ \\
11 tahun & 20 & 14 & $34(8 \%)$ & 104 & $6(1,4 \%)$ & 144 \\
Total & $50(11,7 \%)$ & $34(8 \%)$ & $\mathbf{8 4}(\mathbf{1 9 , 7 \% )}$ & $(24,4 \%)$ & $\mathbf{2 2}(\mathbf{5 , 2 \%})$ & $(33,8 \%)$ \\
& & & & $\mathbf{3 2 0}$ & & $\mathbf{4 2 6}$ \\
& & & & $\mathbf{( 7 5 , 1 \% )}$ & & $\mathbf{( 1 0 0 \% )}$
\end{tabular}

Usia subjek penelitian berkisar antara 8-11 tahun dan didominasi oleh subjek yang berusia 11 tahun. Jumlah subjek dengan status gizi lebih terbanyak ditemukan pada subjek usia 11 tahun $(8 \%)$, status gizi normal terbanyak pada subjek usia 11 tahun $(24,4 \%)$, dan status gizi kurang terbanyak pada subjek usia 8 tahun $(1,6 \%)$. 
Tabel 2. Karakteristik subjek penelitian berdasarkan usia dan jenis kelamin pada kelompok kasus dan kontrol

\begin{tabular}{lccc}
\hline \multicolumn{1}{c}{ Karakteristik } & Kasus $(\mathbf{n}=\mathbf{3 2})$ & Kontrol $(\mathbf{n}=\mathbf{3 2})$ & Total \\
\hline Jenis Kelamin & & & \\
Laki-laki & $16(50 \%)$ & $16(50 \%)$ & 32 \\
Perempuan & $16(50 \%)$ & $16(50 \%)$ & 32 \\
$\quad$ Total & $32(100 \%)$ & $32(100 \%)$ & 64 \\
Usia & & & \\
8 tahun & $12(37,5 \%)$ & $12(37,5 \%)$ & 24 \\
9 tahun & $8(25 \%)$ & $8(25 \%)$ & 16 \\
10 tahun & $2(6,25 \%)$ & $2(6,25 \%)$ & 4 \\
11 tahun & $10(31,25 \%)$ & $10(31,25 \%)$ & 20 \\
Total & $32(100 \%)$ & $32(100 \%)$ & 64 \\
\hline
\end{tabular}

Jenis kelamin subjek penelitian adalah 32 anak berusia 8 tahun sebanyak 12 anak $(37,5 \%), 11$ laki-laki (50\%) dan anak perempuan sebanyak 32 tahun sebanyak 10 anak (31,25\%), 9 tahun anak (50\%). Subjek dengan umur termuda adalah 8 sebanyak 8 anak (25\%) dan 10 tahun sebanyak 2 tahun dan umur tertua adalah 11 tahun. Subjek anak $(6,25 \%)$.

Tabel 3. Kebiasaan Sarapan

\begin{tabular}{lcccc}
\hline & \multicolumn{2}{c}{ Kasus } & \multicolumn{2}{c}{ Kontrol } \\
\cline { 2 - 5 } & $\mathrm{N}$ & $\%$ & $\mathrm{~N}$ & $\%$ \\
\hline Sarapan & & & & \\
$-\quad$ Tidak biasa & 13 & 40,62 & 15 & 46,87 \\
$-\quad$ Biasa & 19 & 59,37 & 17 & 53,13 \\
$-\quad$ TOTAL & 32 & 100 & 32 & 100 \\
\hline
\end{tabular}

Tabel 3 menunjukkan subjek yang tidak biasa biasa sarapan pada kelompok kasus lebih tinggi sarapan pada kelompok kontrol lebih tinggi jika dibandingkan dengan kelompok kontrol. dibandingkan kelompok kasus dan subjek yang

Tabel 4. Kebiasaan Jajan

\begin{tabular}{lcccc}
\hline & \multicolumn{2}{c}{ Kasus } & \multicolumn{2}{c}{ Kontrol } \\
\cline { 2 - 5 } & $\mathrm{N}$ & $\%$ & $\mathrm{~N}$ & $\%$ \\
\hline Jajan & & & & \\
$-\quad$ Biasa & 29 & 90,62 & 17 & 53,13 \\
$-\quad$ Tidak biasa & 3 & 9,38 & 15 & 46,87 \\
$-\quad$ TOTAL & 32 & 100 & 32 & 100 \\
\hline
\end{tabular}

Tabel 4 menunjukkan subjek pada kelompok kasus dengan kategori biasa jajan lebih tinggi jika dibanding dengan kelompok kontrol, dan subjek yang tidak biasa jajan pada kelompok kontrol lebih tinggi dibandingkan kelompok kasus.

\section{B. Analisis Bivariat}

Hubungan antara masing-masing variabel bebas dengan variabel terikat diuji menggunakan uji $M c$ Nemar

Tabel 5. Tabulasi Silang Kebiasaan Sarapan dengan Kebiasaan Jajan

\begin{tabular}{|c|c|c|c|c|c|}
\hline & \multicolumn{4}{|c|}{ Sarapan } & \multirow[b]{2}{*}{ TOTAI } \\
\hline & $\begin{array}{l}\text { Tidak } \\
\text { biasa }\end{array}$ & $\%$ & Biasa & $\%$ & \\
\hline Jajan & & & & & \\
\hline - Biasa & 28 & 43,7 & 18 & 28,12 & 46 \\
\hline - $\quad$ Tidak biasa & 0 & 6 & 18 & 28,12 & 18 \\
\hline - $\quad$ TOTAL & 28 & 0 & 36 & & 64 \\
\hline
\end{tabular}




\begin{tabular}{lll}
\hline & 56,24 & $100 \%$ \\
6 & & \\
& & \\
\end{tabular}

Tabel 7 menunjukkan 28 subjek $(43,76 \%)$ tidak biasa sarapan dan biasa jajan, 18 subjek $(28,12 \%)$ biasa sarapan dan biasa jajan, 18 subjek $(28,12 \%)$ biasa sarapan tetapi tidak biasa jajan, dan tidak terdapat subjek yang tidak biasa sarapan dan tidak biasa jajan (0\%). Kebiasaan sarapan dengan kebiasaan jajan terdapat hubungan yang bermakna secara statistik yaitu subjek yang tidak biasa sarapan akan berisiko menjadi biasa jajan sebesar 1,5 kali. $(\mathrm{p}=0,000 ; \mathrm{OR}=1.500 ; \mathrm{CI}=0.361-0.693$ )

Tabel 6. Tabulasi Silang Kebiasaan Sarapan dengan Status Gizi

\begin{tabular}{lcccccc}
\hline & \multicolumn{7}{c}{ Kontrol } \\
\cline { 2 - 7 } & $\begin{array}{c}\text { Tidak } \\
\text { biasa }\end{array}$ & $\%$ & Biasa & \% & Total & \% \\
\hline Kasus & 5 & 15,6 & 8 & 25 & 13 & 40,6 \\
$-\quad$ Tidak biasa & 10 & 31,25 & 9 & 28,1 & 19 & 59,4 \\
$-\quad$ Biasa & 16 & 50 & 16 & 50 & 32 & 100 \\
\hline
\end{tabular}

Tabel 5 menunjukkan pasangan subjek kasus yang biasa sarapan dengan subjek kontrol yang tidak biasa sarapan memiliki jumlah tertinggi yaitu $34,4 \%$ dan jumlah terendah terdapat pada pasangan subjek kasus yang tidak biasa sarapan dengan subjek kontrol yang biasa sarapan yaitu $21,9 \%$.
Terdapat 12 subjek kasus yang tidak biasa sarapan $(37,5 \%)$ dan 16 subjek kontrol yang tidak biasa sarapan (50\%). Tidak biasa sarapan bukan merupakan faktor yang berhubungan dengan terjadinya status gizi lebih secara statistik. $(\mathrm{p}=0,614 ; \mathrm{OR}=0,636 ; \mathrm{CI}=0.479-3.470$ )

Tabel 7. Tabulasi Silang Kebiasaan Jajan dengan Status Gizi

\begin{tabular}{lcccccc}
\hline & \multicolumn{7}{c}{ Kontrol } \\
\cline { 2 - 7 } & Biasa & $\%$ & $\begin{array}{c}\text { Tidak } \\
\text { biasa }\end{array}$ & $\%$ & Total & $\%$ \\
\hline Kasus & 15 & 46,9 & 14 & 43,75 & 29 & 90,65 \\
$-\quad$ Biasa & 2 & 6,25 & 1 & 3,1 & 3 & 9,35 \\
$-\quad$ Tidak biasa & 17 & 53,15 & 15 & 46,85 & 32 & 100 \\
\hline
\end{tabular}

Tabel 6 menunjukkan pasangan subjek kasus dan kontrol yang biasa jajan memiliki jumlah tertinggi yaitu $46,9 \%$ dan jumlah terendah terdapat pada pasangan subjek kasus dan kontrol yang tidak biasa jajan yaitu $3,1 \%$. Terdapat 29 subjek kasus yang biasa jajan $(90,65 \%)$, dan 17 subjek kontrol yang biasa jajan $(53,15 \%)$. Terdapat hubungan yang bermakna antara kebiasaan jajan dengan status gizi lebih secara statistik dengan risiko sebesar 7 kali terhadap terjadinya status gizi lebih. $(\mathrm{p}=0,001 ; \mathrm{OR}=7.012 ; \mathrm{CI}=2.153-33.788)$

\section{PEMBAHASAN}

Prevalensi overweight dan obesitas di kecamatan Pedurungan ini tergolong tinggi yaitu $19,7 \%$. Subjek dengan status gizi lebih terbanyak ditemukan pada usia 11 tahun (8\%). Obesitas pada dewasa dapat bermula semenjak anak-anak, dan obesitas dapat menjadi faktor risiko dari berbagai penyakit degeneratif seperti hipertensi, diabetes mellitus, dan jantung. ${ }^{14,15}$

Pada penelitian ini subjek yang tidak biasa sarapan pada kelompok kasus tergolong tinggi yaitu 40,6\%. Prevalensi ini lebih tinggi dibandingkan penelitian Triyanti di SD Citarum 01,02,03,04 Semarang yang menunjukkan terdapat $34,83 \%$ anak SD tidak biasa sarapan. ${ }^{8}$ Hal ini sesuai penelitian yang dilakukan oleh Rampersaud GC di Amerika Serikat bahwa anak atau remaja yang meninggalkan sarapan akan berisiko untuk menjadi overweight atau obesitas dibandingkan mereka yang sarapan. ${ }^{5}$ Berdasarkan hasil uji 
bivariat, ditemukan bahwa tidak biasa sarapan bukan merupakan faktor yang berhubungan dengan terjadinya status gizi lebih secara statistik $(\mathrm{p}=0.614 ; \quad \mathrm{OR}=0,636 ; \quad \mathrm{CI}=0.479-3.470)$, tetapi berhubungan dengan kebiasaan jajan di sekolah $(\mathrm{p}=0.000)$.

Pada penelitian ini ditemukan kualitas diet yang kurang baik saat sarapan yaitu hanya mengkonsumsi makanan sumber karbohidrat dan protein seperti nasi dan telur ceplok tanpa sayur maupun buah-buahan yang berakibat rendahnya asupan serat saat sarapan. Terdapat $21,87 \%$ subjek pada kelompok kasus yang biasa sarapan dengan energi kurang dari kebutuhan dan 15,6\% subjek yang biasa sarapan dengan energi melebihi kebutuhan. DEPKES RI mengatakan sarapan yang baik seharusnya mengandung energi $20-25 \%$ dari kebutuhan energi total sehari, karbohidrat (60$68 \%)$, protein $(15-25 \%)$, lemak $(12-15 \%)$, dan vitamin/mineral serta tinggi serat. ${ }^{7,16}$

Hasil penelitian tentang kebiasaan jajan menunjukkan 29 subjek $(90,65 \%)$ pada kelompok kasus dan 17 subjek $(53,15 \%)$ pada kelompok kontrol termasuk dalam kategori biasa jajan. Rerata energi makanan jajanan untuk kelompok kasus adalah $326.38 \pm 98.6 \mathrm{kkal}$, lebih tinggi dari kebutuhan yaitu 180 kkal untuk anak usia 7-9 tahun dan 205 kkal untuk usia 10-12 tahun. Penelitian ini sejalan dengan survei yang dilaksanakan Badan POM RI tahun 2008 pada 4.500 SD di $79 \mathrm{Kab} /$ Kota di 18 propinsi di Indonesia yang menunjukkan bahwa sebanyak $48 \%$ responden memiliki frekuensi jajan sering/selalu yaitu $\geq 4$ kali per minggu dengan total energi konsumsi pangan jajanan adalah 384 kkal (tergolong lebih). ${ }^{10}$ Makanan jajanan yang paling banyak dikonsumsi oleh subjek pada kelompok kasus adalah makanan tinggi kalori seperti mie goreng, nasi goreng, burger, batagor, sosis, coklat, dan gorengan.

Prentice dan Jebb menyimpulkan bahwa kelebihan energi dalam mengkonsumsi makanan seperti fast food dapat mengakibatkan obesitas, ${ }^{17}$ dan diperkuat oleh penelitian Padmiari terhadap terhadap 154 anak SD di kota Denpasar yang menunjukkan bahwa prevalensi obesitas pada anak SD yang terbiasa mengkonsumsi makanan cepat saji (fast food) cukup tinggi (13,6\%) dan berisiko 6 kali lebih tinggi untuk menjadi obesitas. ${ }^{18}$ Berdasarkan hasil uji bivariat, ditemukan bahwa terdapat hubungan yang bermakna antara kebiasaan jajan dengan status gizi lebih secara statistik dan biasa jajan memiliki risiko sebesar 7 kali terhadap terjadinya status gizi lebih. $(\mathrm{p}=0.001$; $\mathrm{OR}=7.012 ; \mathrm{CI}=2.153-33.788$ ).

Berdasarkan hasil penelitian terdapat 28 subjek $(43,76 \%)$ yang tidak biasa sarapan tetapi biasa jajan, dan tidak terdapat subjek yang tidak biasa sarapan tetapi tidak biasa jajan $(0 \%)$. Prevalensi subjek tidak biasa sarapan tetapi biasa jajan ini tergolong tinggi dan sesuai dengan penelitian Rampersaud dan Utter bahwa obesitas dapat terjadi karena ketika anak tersebut melewatkan sarapan dan merasa lapar maka mereka akan mengkonsumsi makanan berkalori lebih tinggi yang didapatkan dari makanan jajanan. ${ }^{5}$ Berdasarkan hasil uji bivariat, ditemukan bahwa kebiasaan sarapan dengan kebiasaan jajan terdapat hubungan yang bermakna secara statistik yaitu subjek yang tidak biasa sarapan akan berisiko menjadi biasa jajan sebesar 1,5 kali. ( $\mathrm{p}=0,000$; $\mathrm{OR}=1.500 ; \mathrm{CI}=0.361-0.693$ ).

\section{KETERBATASAN PENELITIAN}

Penelitian ini memiliki keterbatasan dalam pelaksanaannya, yaitu beberapa faktor lain seperti komposisi lemak tubuh, aktivitas fisik, lingkungan tempat tinggal, karakteristik orang tua dan asupan zat gizi seperti karbohidrat, protein, lemak yang tidak diteliti yang kemungkinan juga berperan dalam kejadian overweight dan obesitas pada anak sekolah dasar.

\section{SIMPULAN}

Prevalensi overweight dan obesitas yang cukup tinggi ditemukan di 2 SD di kecamatan Pedurungan Semarang yaitu 50 anak $(11,7 \%)$ dan 34 anak (8\%) dari total populasi kelas III-VI dimana usia terbanyak status gizi lebih adalah 11 tahun.

Tidak terdapat hubungan antara kebiasaan sarapan dengan status gizi lebih secara statistik, tetapi kebiasaan sarapan berhubungan dengan kebiasaan jajan di sekolah dengan risiko sebesar 1,5 kali. Terdapat hubungan yang bermakna antara kebiasaan jajan dengan status gizi lebih secara statistik dan biasa jajan memiliki risiko sebesar 7 kali terhadap terjadinya status gizi lebih.

\section{SARAN}

Melakukan penyuluhan Komunikasi Informasi dan Edukasi (KIE) dalam mata pelajaran Penjaskes (Pendidikan Jasmani dan Kesehatan) untuk memberikan pengetahuan gizi pada anakanak SD mengenai kebiasaan sarapan dan makanan jajanan yang baik dan sehat. Di samping itu, perlu 
dilakukan intervensi terhadap pihak-pihak terkait mengenai jajanan sehat seperti terhadap orang tua, guru, dan penjual makanan jajanan.

\section{DAFTAR PUSTAKA}

1. Direktorat Jenderal Bina Gizi dan KIA. Rencana Aksi Pembinaan Gizi Masyarakat (RAPGM) Tahun 2010 - 2014. Jakarta, 2011.

2. Ali, Khomsan. Pangan dan Gizi untuk Kesehatan. Jakarta: PT. Rajagrafindo. Persada; 2003.

3. DEPKES RI, 1996.Panduan 13 Dasar Pesan Gizi Seimbang, Jakarta Edisi II.

4. Latifah M Al-Oboudi. Impact Of Breakfast Eating Pattern On Nutritional Status, Glucose Level, Iron Status In Blood, And Test Grade Among Upper Primary School Girls In Riyadh City, Saudi Arabia. Pakistan Journal Of Nutrition 9 (2): 106-111, 2010.

5. Rampersaud, G. C., Pereira, M. A., Girard, B. L., Adams, J., \& Metzl, J. D. (2005). Breakfast Habits, Nutritional Status, Body Weight, and Academic Performance in Children and Adolescents. Journal of the American Dietetic Association, 105(5), 743760.

6. Utter, J., Scragg, R., Mhurchu, C. \& Schaaf, D. (2007). At home Breakfast Consumption Among New Zealand Children: Associations With Body Mass Index And Related Nutrition Behaviors. Journal of the American Dietetic Association, 107, 570-576.

7. TVE Kral, LM Whiteford, M Heo (2011). Effects Of Eating Breakfast Compared With Skipping Breakfast On Ratings Of Appetite And Intake At Subsequent Meals In 8- To 10-Y-Old Children. Journal of the American Clinical Nutrition,

8. Triyanti. 2005. Hubungan Kebiasaan Makan Pagi dengan Prestasi Belajar pada Anak SD Kelas V Sekolah Dasar Negeri Citarum 01-02-03-04 Semarang Tahun 2005 [Skripsi]. Semarang : Universitas Negeri Semarang 01- 02-03-04 Semarang

9. DEPKES RI, 2011. Jejaring Informasi Pangan dan Gizi. Jakarta ; Edisi II.

10. BPOM RI, 2009. Pangan Jajanan Anak Sekolah. Jakarta : Edisi II.

11. Adair LS, Popkin BM. Are child eating patterns being transformed globally?. Obesity Research. 2005; 13. p. 1281-1299.

12. Mexitalia M, Susanto JC, Faizah Z, Hardian. Hubungan Pola Makan Dan Aktivitas Fisik Pada Anak Dengan Obesitas Usia 6-7 Tahun Di Semarang. M MedIndones.2005;40-62-70.

13. Sjarif DR. Childhood And Adolescent Obesity Studies In Indonesia. In : Lukito W, editor. The $5^{\text {th }}$ National Obesity Symposium; 2006; Jakarta. ISO; 2006.

14. Khairil Anuar, Mohamad GM (2011). The Association Of Breakfast Consumption Habit, Snacking Behavior And Body Mass Index Among University Students. American Journal Of Food And Nutrition.1.2.55.60.
15. Chanyang Min, Hwayoung Noh, Yun-Sook Kang. Skipping Breakfast Is Associated With Diet Quality And Metabolic Syndrome Risk Factors Of Adults. Nutrition Research and Practice (Nutr Res Pract) 2011;5(5):455-463

16. Affenito SG, Thompson DR, Barton BA, Franko DL, Daniels SR, Obarzanek E, Schreiber GB, Striegel-Moore. "Breakfast Consumption by African-American and White Adolescent Girls Correlates Positively with Calcium and Fiber Intake and Negatively with Body Mass Index." Journal of the American Dietetic Association 2005;105:938945.

17. Prentice, A. \& Jebb, S. (2003) Fast Foods, Energy Density And Obesity: A Possible Mechanistic Link. Obesity Reviews, 4, 187-194.

18. Eka Padmiari, Ida Ayu, Mukhlis.( 2003) Konsumsi Fast Food Sebagai Faktor Risiko Obesitas Pada Anak SD. Medika : Jurnal Kedokteran Indonesia, 3, 610.5 Med,29,159-165. 